\title{
WORKSHOP PEMBUATAN HANDSANITIZER SPRAY GEL
}

\author{
Pramulani Mulya Lestari, Ani Pahriyani, Supandi \\ Fakultas Farmasi dan Sains Universitas Muhammadiyah Prof. DR. HAMKA, Jakarta \\ 1email:pramulani_mlestari@uhamka.ac.id
}

\begin{abstract}
Systemic and interconnected health problems are still a challenge for partners, children who are often sick such as diarrhea, flu cough, fever is often a problem in the RPTA and RW 03 environment of West Jakarta, due to the rapid transmission and continuous transmission that is considered to inhibit the motor activity of children who are developing. in an effort to achieve good health quality and equitable well-being for the entire population as well as the lack of knowledge and ideas of the community towards the manufacture of products that can be used to maintain cleanliness. Solving the problems that exist in the community in supporting health maintenance is necessary to be held workshop on the manufacture of hand satizer gel spray. Plants that can be used as a natural ingredient of handsanitizer production namely Belimbing Wuluh (Averhoa belimbii). Belimbing Wuluh (Averhoa belimbii) contains beneficial chemical compounds, one of which flavonoids are thought to be active anti-bacterial compounds. This activity is expected to increase the awareness, willingness and ability of individuals, as well as the public to care about health problems as well as play an active role in all forms of health efforts Keywords: handsanitizer, gel spray, Averhoa belimbii
\end{abstract}

\begin{abstract}
Abstrak
Permasalahan kesehatan yang sistemik dan saling berkaitan masih menjadi tantangan mitra, anak - anak yang sering sakit seperti diare, batuk flu, demam seringkali menjadi masalah dalam lingkungan RPTA dan RW 03 kemanggisan Jakarta Barat, karena penularan yang begitu cepat dan terjadi secara terus menerus sehingga dianggap menghambat aktivitas motorik anak - anak yang sedang berkembang. dalam upaya mencapai kualitas kesehatan yang baik dan kesejahteraan yang merata bagi seluruh penduduk serta minimnya pengetahuan dan ide masyarakat terhadap pembuatan produk yang dapat digunakan untuk memelihara kebersihan. Pemecahan masalah yang ada pada masyarakat tersebut dalam mendukung pemeliharaan kesehatan yaitu perlu dilalukan workshop mengenai pembuatan hand satizer gel spray. Tanaman yang dapat dimanfaatkan sebagai bahan alami pembuatan hand sanitizer yaitu Belimbing Wuluh (Averhoa belimbii). Belimbing Wuluh (Averhoa belimbii) mengandung unsur-unsur senyawa kimia yang bemanfaat, salah satunya flavonoid diduga merupakan senyawa aktif anti bakteri. Kegiatan ini diharapkan dapat meningkatkan kesadaran, kemauan dan kemampuan individu, maupun masyarakat untuk peduli akan masalah kesehatan serta berperan aktif dalam segala bentuk upaya kesehatan
\end{abstract}

Kata Kunci: handsanitizer, gel spray, Belimbing wuluh

Submitted: $2020-08-25$ Revised: $2020-10-08$ Accepted: $2020-10-11$

\section{Pendahuluan}

Kesehatan merupakan aspek yang sangat penting bagi kehidupan, pemberian pelatihan workshop pembuatan hand sanitizer gel spray untuk memelihara kebersihan tangan dirasa juga perlu. Tangan merupakan media yang sangat mudah untuk penyebaran penyakit dan infeksi pada manusia karena tangan sangat sering melakukan kontak dengan lingkungan, serta kontak dengan area mata, hidung maupun mulut yang sangat rentan untuk jalan infeksi bakteri (WHO, 2005). Cuci tangan menggunakan sabun dan air merupakan cara yang paling umum dilakukan untuk menjaga kebersihan tangan. 
Saat ini banyak ditawarkan pembersih tangan berupa hand sanitizer karena penggunaannya lebih praktis.

Hand sanitizer (antiseptik tangan) adalah produk kesehatan yang secara instant dapat mematikan kuman tanpa menggunakan air, dapat digunakan kapan saja dan dimana saja, misalnya setelah memegang uang, sebelum makan, setelah dari toilet dan setelah membuang sampah. Akan tetapi penggunaan alkohol pada kulit dirasa kurang aman karena alkohol adalah pelarut organic yang dapat melarutkan sebum pada kulit, dimana sebum tersebut bertugas melindungi kulit dari mikroorganisme (Retnosari dan Isadiartuti, 2006). Selain itu alkohol memiliki sifat mudah terbakar dan dapat menyebabkan iritasi dengan memicu kekeringan pada kulit (Block, 2001). Berdasarkan permasalahan tersebut maka muncul pertimbangan untuk menghilangkan kandungan alkohol pada sediaan hand sanitizer dengan mencoba menggunakan bahan alami.

Ada banyak tanaman yang dapat dimanfaatkan sebagai bahan alami pembuatan hand sanitizer, salah satunya yaitu Belimbing Wuluh (Averhoa belimbii). Belimbing Wuluh (Averhoa belimbii) merupakan salah satu tanaman yang mudah didapatkan di lingkungan masyarakat dan banyak digunakan sebagai ramuan tradisional. Belimbing Wuluh (Averhoa belimbii) mengandung unsur-unsur senyawa kimia yang bemanfaat, seperti senyawa oksalat, saponin, minyak menguap, fenol, flavonoid dan pectin. Di mana flavonoid diduga merupakan senyawa aktif anti bakteri yang terkandung dalam buah belimbing wuluh (Zakaria et al.,2007).

Fakultas Farmasi dan Sains Universitas Muhammadiyah Prof. DR. HAMKA (UHAMKA) merupakan fakultas yang sebagian besar dosennya adalah apoteker, sehingga dirasa perlu untuk workshop pembuatan hand sanitizer spray gel.

Pada kegiatan ini, yang akan menjadi objek adalah warga kemanggisan, Jakarta Barat. Kemanggisan memiliki beberapa Rukun Warga yang lebih dari separuhnya adalah pemukiman pandat penduduk. Padatnya penduduk menjadi salah satu faktor adanya masalah-masalah kesehatan seperti pandemic covid 19 seperti saat ini, serta mudahnya penyebaran penyakit infeksi. Kondisi ekonomi dan background pendidikan yang bervariasi membuat penanganan penyakit terutama dalam hal pengobatan sangat bervariasi. Perguruan Tinggi Muhammadiyah ikut membantu dan memberikan pemahaman kepada lingkungan sekitar untuk memiliki keterampilan pembuatan handsanitizer spray gel.

\section{Metode}

Target pada pengabdian masyarakat ini adalah warga kemanggisan khususnya RW 03 kelurahan kemanggisan dan warga-warga di sekitar RTPA Manggis Kemanggisan, Palmerah, Jakarta barat. Warga yang menjadi sasaran adalah ibu-ibu dan anak-anak khususnya yang berada di lingkungan RW. 03 Kemanggisan

Permasalahan kesehatan yang sistemik dan saling berkaitan masih menjadi tantangan mitra, anak - anak yang sering sakit seperti diare, batuk flu, demam seringkali menjadi masalah dalam lingkungan RPTA dan RW 03 kemanggisan Jakarta Barat, karena penularan yang begitu cepat dan terjadi secara terus menerus sehingga dianggap menghambat aktivitas motorik anak - anak yang sedang berkembang. dalam upaya mencapai kualitas kesehatan yang baik dan kesejahteraan yang merata bagi seluruh penduduk serta minimnya pengetahuan dan ide masyarakat terhadap pembuatan produk 
yang dapat digunakan untuk memelihara kebersihan.

Pemecahan masalah yang ada pada masyarakat tersebut dalam mendukung pemeliharaan kesehatan yaitu perlu dilalukan workshop mengenai pembuatan hand satizer gel spray. Tim pelaksana merupakan staf pengajar dengan bidang keahlian teknologi farmasi, kimia farmasi dan farmasi klinis yang secara khusus memahami dan berkompeten. sehingga diharapkan program ini dapat menghasilkan luaran berupa keterampilan masyarakat dalam membuat handsanitizer spray gel dari sari buah belimbing wuluh

\section{Hasil dan Pembahasan}

Kegiatan pelatihan pembuatan handsanitizer dengan belimbing wuluh sebagai bahan aktif dalam upaya pemeliharaan kesehatan. Pemeliharaan kesehatan merupakan usaha pencegahan penyakit agar setiap orang dapat produktif secara social maupun ekonomi. Handsanitizer ini selain dapat digunakan dalam rangka pemeliharaan kesehatan diri dan keluarga juga dapat dimanfaatkan untuk meningkatkan perekonomian, karena kesadaran masyarakat akan hidup bersih dan sehat terus meningkat setiap tahunnya. sehingga upaya - upaya pemeliharaan kesehatan cukup popular akhir-akhir ini. menyikapi hal tersebut maka tim pengabdian FFS UHAMKA merasa perlu untuk memberikan edukasi dan pelatihan mengenai pemeliharaan kesehatan melalui pembuatan handsanitizer.

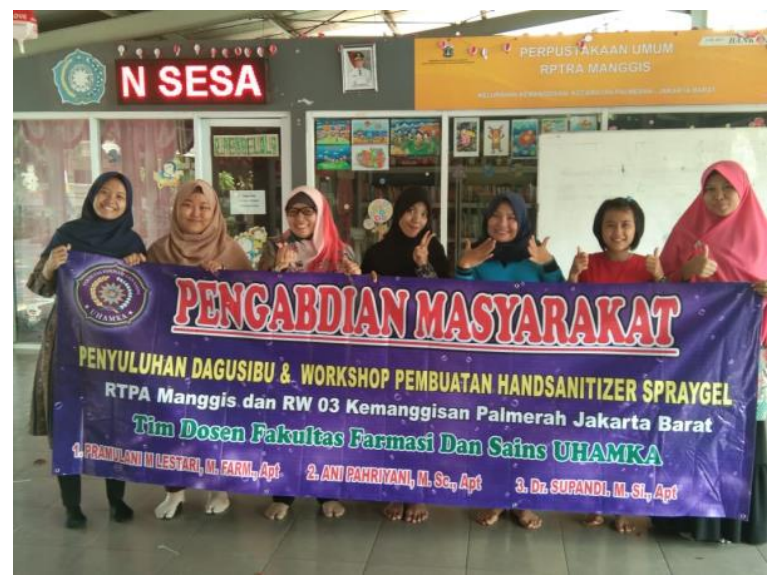

Gambar 1. Kegiatan pengabdian masyarakat

Handsanitizer merupakan salah satu produk yang dapat digunakan dalam upaya pemeliharaan kesehatan tersebut. Berdasarkan bahan aktif yang digunakan, secara umum hand sanitizer diklasifikasikan menjadi dua jenis yaitu handsanitizer dengan basis alcohol dan nonalkohol. pada handsanitizer berbasis alcohol, alcohol yang digunakan $60-95 \%$ dapat dalam bentuk etanol, isopropan ataupun n-propan (Ewen, 2010). Alkohol bekerja dengan cara mendenaturasi protein pada beberapa jenis mikroorganisme (Raymon, 2010). Sedangkan handsanitizer berbasisn nonalkohol biasanya mengandung desinfektan seperti benzalkonium klorida (BAC), atau pada agen antimikroba, seperti triclosan (Ewen, 2010).

Pada pengabdian masyarakat ini, tidak menggunakan handsanitizer yang berbasis alcohol tapi menggunakan sari buah belimbing wuluh (Averhoa belimbii)sebagai bahan aktif, karenah buah ini banyak ditemukan di perkarangan rumah warga yang 
pemanfaatannya saat ini hanya sebatas bumbu masakan dan selebihnya terbuang begitu saja. Melihat potesi dalam buah belimbing wuluh yang cukup besar yang pada penelitian Zakaria, 2007 menyebutkan bahwa buah belimbing wuluh mengandung flavonoid yang dapat digunakan sebagai antibakteri serta Datu et al 2015 menyebutkan bahwa sari buah belimbing wuluh dapat menghambat pertumbuhan Pseudomonas aeruginosa dan Staphylococcus epidermidis. Bakteri gram negative Pseudomonas aeruginosa, dapat mengganggu pertahanann tubuh khususnya bila bakteri tersebut masuk pada jaringan luka pada kulit yang menimbulkan nanah berwarna merah kehijauan. sedangkan Staphylococcus epidermidis merupakan bakteri gram positif yang merupakan flora normal kulit, yang pada kondisi tertentu dapat menyebabkan infeksi kulit ringan disertai abses.

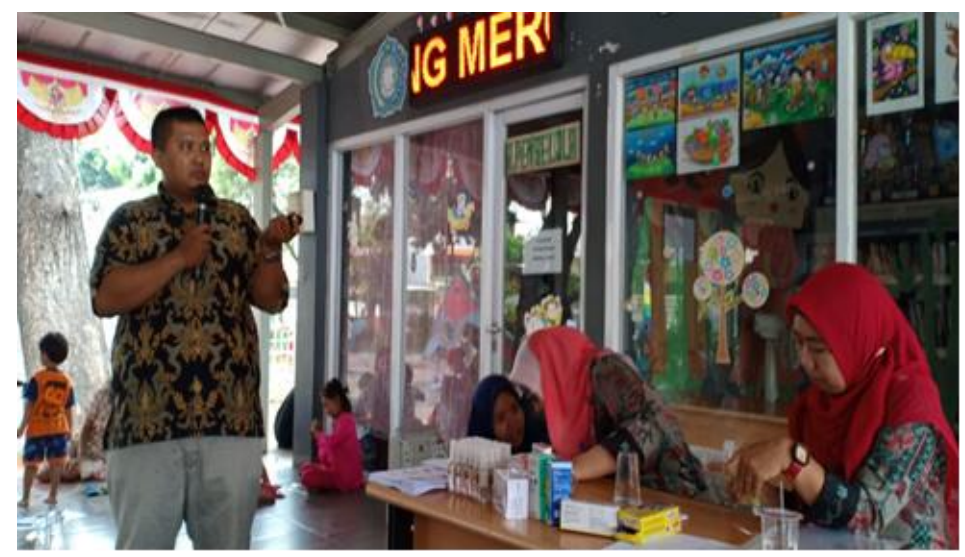

Gambar 2. pemaparan mengenai handanitizer

Sari buah belimbing wuluh dibuat dengan menghancurkan buah belimbing wuluh yang sudah dicuci dengan air mengalir menggunakan blender selanjutnya filtrate disaring/dipisahkan dengan seratnya. sari yang didapat dimasukkan dalam formula spray gel yang terdiri dari carbopol, air, propilenglikol dan nipagin. dipilihnya bentuk sediaan sray gel bertujuan agar handsanitizer lebih mudah digunakan dan mudah mengalir/menyebar merata dipermukaan kulit/tangan dibanding bentuk sediaan gel ataupun bentuk sediaan cairnya yang lebih mudah tumpah dan boros dalam penggunaan.

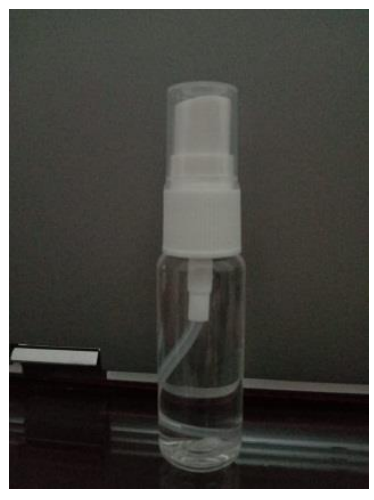

Gambar 3. sprey gel handsanitizer belimbing wuluh 
Sebelum tim pengabdian masyarakat memberikan pelatihan pembuatan handsanitizer, formula hansanitizer dioptimasi di laboratorium Fakultas Farmasi dan Sains UHAMKA untuk mendapatkan spray gel handsanitizer yang nyaman digunakan dan cepat mengering di tangan. formula yang optimal inilah yang kemudian digunakan untuk pelatihan bagi warga kemanggisan.

Masyarakat di Kemanggisan sangat antusias melihat demo pembuatan handsanitizer spray gel serta mempraktekan/mengerjakan sendiri pembuatan handsanitizer yang relative mudah dan murah ini dengan didampingi tim dosen FFS UHAMKA dan mahasiswa FFS UHAMKA yang sudah terbiasa dan sedang melaksanakan penelitian mengenai sediaan handsanitizer spray gel ini.

\section{Kesimpulan}

Tim pengabdian masyarakat FFS UHAMKA melaksanakan kegiatan ini untuk meningkatkan kesadaran, kemauan dan kemampuan individu, maupun masyarakat untuk peduli akan masalah kesehatan serta berperan aktif dalam segala bentuk upaya kesehatan. Upaya yang dilakukan disambut antusias oleh masyarakat. selanjutnya disarankan untuk memberikan keterampilan keterampilan lain yang terkait kebersihan dan kesehatan masyarakat.

\section{Daftar Pustaka}

Anonim. 1986. Sediaan Galenik. Departemen Kesehatan Republik Indonesia, Jakarta. Anonim. 1983. Farmakologi dan Terapi edisi II. Bag. Farmakologi FK UI. Jakarta. Anonim. 1997. Farmakope Indonesia Edisi IV. Departemen Kesehaan Republik Indonesia Block, S. 2001. Disinfection, Sterilization and Preservation, edisi 4, Williams and Wilkins. USA

Datu Jeryanti Tandi, Nur Mita, Rolan Rusli. 2015. Aktivitas Antibakteri Sari Buah Belimbing Wuluh (Averrhoa bilimbi Linn.) Terhadap Bakteri Pseudomonas Aeruginosa Dan Staphylococcus Epidermidis. Prosiding Seminar Nasional Kefarmasian Ke1 "Potensi Produk Farmasi dari Bahan Alam Hayati untuk Pelayanan Kesehatan di Indonesia serta Strategi Penemuannya.

Ewen C.D. Todd et al. 2010. Outbreaks Where Food Workers Have Been Implicated in the Spread of Foodborne Disease. Part 10. Alcohol-Based Antiseptics for Hand Disinfection and a Comparison of Their Effectiveness with Soaps. Journal of Food Protection. 73(11):2128-40.

Kahrs, R.F. 1995. General Disinfection Guidelines. Rev. sci. tech. Off. Int. Epiz. 14 (1) http://iaisumbar.net/site/wp-content/uploads/2014/09/GKSO-Pedoman-Pelaksanaan.pdf

Raymond Li. 2010. Alcohol-Based Hand Sanitizer Safety. B.C. Drug and Poison Information Centre.

Retnosari dan Isadiartuti, D. 2006. Studi Efektivitas Sediaan Gel Antiseptik Tangan Ekstrak Daun Sirih (Piper betle Linn.). Majalah farmasi Indonesia.

Sutjipto. 2001. Inventaris Tanaman Obat Indonesia, Jilid 2. Departemen Kesehatan dan Kesejahteraan Sosial Republik Indonesia. Badan Penelitian dan Pengembangan Kesehatan. Jakarta

Winarti, C. dan Nurdjanah, N. 2005. Peluang Tanaman Rempah dan Obat Sebagai Sumber Pangan Fungsional. Jurnal Litbang Pertanian 
Zakaria, Z. A., Zaiton, H., Henie, E. F. P., Mat Jais, A. M., \& Zainuddin, E. N. H. 2007. In vitro Antibacterial Activity of Averrhoa bilimbi L. Leaves and Fruits Extracts. International journal of Tropical Medicine. 2(3):96-100 